\title{
Ponziceuticals within the medical industrial complex
}

I t didn't take long for the metaphors of financial meltdown to infect the lexicon of the medical industrial complex. Faster than you can say "toxic assets," the financial medicine men are out there taking the "pulse" of the economy, demanding governments "inject life" into ailing companies, and generally poking and pontificating over the economy's health like a patient in ICU.

For me, the most resonant moneymedicine metaphor is the one named after Charles Ponzi, who, back in the 1920 s promised investors a 50\% return in a mere 45 days and had people tripping over themselves to hand over their life savings. Nearly a century later, people such as Bernard Madoff, author of the biggest ponzi scheme ever foisted on the public, can still manage to convince thousands of people to shovel billions their way.

"Confidence" men, riffing on nothing save a smile and a convincing story make even honest people forget the truism: "if it sounds too good to be true, it probably is." What about applying that thought to the world of pharmaceuticals, or shall we say, "ponziceuticals"?

There are, after all some striking resemblances between the global $\$ 900$ billion prescription drug market and a ponzi scheme, the sole difference being that unlike a real ponzi scheme the pharmaceutical world does actually sell commodities of tangible benefit. Even so, we've quite frankly seen a lot of ponziceutical operators hyping their assets and hoping that investors (and here I include prescribers and patients) don't lose confidence and stop the flow of revenue.

Consider Exhibit A: the perennial "too-good-to-be-true" television drug advertisement. Wouldn't it be nice if your life, which currently sucks, could be transformed like the woman's on TV into one with picture-perfect health as she romps through a field of daisies and chirping birds, all thanks to a pill of some sort? Confidence, indeed.

With nearly $\$ 5$ billion spent every year on ads such as this the ponziceutical metaphor isn't much of a stretch. It at least makes you wonder how much ebullient confidence and ringing gullibility is mixed in there with the actual products.

Exhibit B in the ponziceutical hypothesis: a recent clinical study so totally out of this world it bore the name of a distant planet. Whatever you might conclude about the jaw-dropping "Jupiter Trial"1 (take home message:

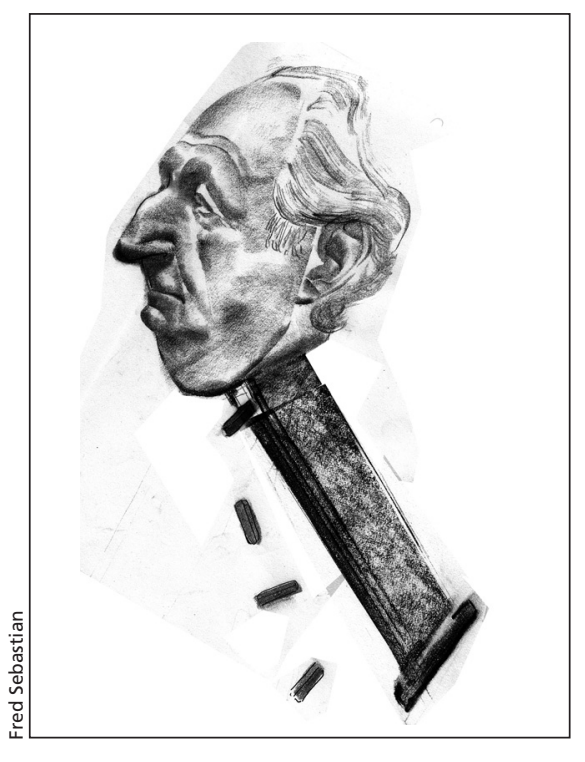

Bernard Madoff, quintessential ponzi schemer.

regardless of your cholesterol level, get your CRP checked and eat statins every day), you can't deny it was seriously red-lining on the gullibility tachometer. Because the reports of the study openly disclosed that the coinventor on the patent for the C-reactive protein test headed up the study, we ordinary rubes, no doubt fortified by such disclosure lined up to whip out our chequebooks and invest in this tidy little bit of pharma ingenuity. Confidence indeed.

Even though the drug industry has proven itself able to produce incredible rates of return for years, (and some terribly helpful drugs along the way) hasn't some of that growth been based on a huge wallop of CEO hubris - spewing confidence?
For Exhibit C I turn to a recent example of Kerry Smith Cox, the CEO of Schering Plough allegedly caught in a ponziceutical scheme. Just before the Enhance Trial results were announced (where Vytorin, their plaque reduction drug, didn't look so hot) she allegedly cashed in her 900000 shares worth a cool US\$28 million. If US federal investigators confirm this and if Martha Stewart's recent jaunt in the jumpsuit provides any foreshadowing, Ms. Cox could also be soon sporting orange attire.

Like any business that is based on murky fundamentals, ponzi executives do what they do best - keep the flame alive and the troops marching in the right direction while some of them are scouting out the exits.

Does this mean there are some serious cracks starting to show in the ponziceutical world? I admit I'm torn. Half of me is saying: hang on, things are looking up and the brave new world of pharmaceuticals is still worth your money. But the other half of me is asking this nagging question: Are those the backs of people I see running for the exits?

\section{Alan Cassels MPA \\ Drug policy researcher \\ University of Victoria \\ Victoria, BC}

\section{REFERENCE}

1. Ridker PM, Danielson E, Fonseca F, et al. Rosuvastatin to prevent vascular events in men and women with elevated C-reactive protein. New Eng J Med 2009;359:2195-207.

The term ponziceutical was picked up from Harriet Rosenberg, a professor of social science at York University in Toronto, Ontario who says that David Lee, a graduate student in communications at the University of South Florida coined the term.

Have you got an opinion about this article? Post your views at www.cmaj.ca. Potential Salon contributors are welcome to send a query to salon@cmaj.ca.

All editorial matter in CMAJ represents the opinions of the authors and not necessarily those of the Canadian Medical Association. 